\title{
PENGOLAHAN LIMBAH KULIT DURIAN MENJADI BIO-BATERAI SEBAGAI ENERGI ALTERNATIF
}

\author{
Whydiantoro' $^{1)}$, Dony Susandi²), Intan Kusumadewi ${ }^{3)}$, Alan Maulana Sidik ${ }^{4)}$ \\ Program Studi Teknik industri, Fakultas Teknik, Universitas Majalengka \\ Email : why@ft.unma.ac.id, dys@ft.unma.ac.id
}

\begin{abstract}
ABSTRACS
Durian is one of the most popular fruits in Indonesia. The fruit that has a distinctive taste and aroma is very popular with most people. The sweet fruit flavor and the fragrant aroma of the fruit are the main attraction for durian lovers. The color of the flesh varies, some are white, yellow, and orange and the fruit is complemented by the presence of calories, vitamins, fat and protein. During this time, the part of durian fruit that is more commonly consumed is the portion of the fruit consumed. If you look at the usefulness of durian, it turns out that not only the flesh is consumed, but if explored more deeply can be found a variety of benefits from all parts of the durian fruit such as durian skin parts. Processing of durian skin waste which will later be used as bio-batteries as alternative energy provide a real contribution in realizing the development of science and technology, especially the method of processing durian skin waste into bio-batteries. Not only limited to the processing of durian skin waste will be a useful source of information in the effort to use durian skin waste, so that local people can use it and can be used as an alternative solution to overcome the energy crisis by using biobatteries as renewable energy that is environmentally friendly. Durian skin waste treatment is expected to create a process of processing durian skin into bio-batteries which will later become an alternative energy that is a solution to overcome the energy crisis by using biobatteries as environmentally friendly renewable energy, where the results of this study will be very useful for the community.
\end{abstract}

Keywords: Bio-battery, Durian Skin Waste

\section{PENDAHULUAN}

Kenyataan nya, kulit dan biji durian hanya dibuang begitu saja tanpa dimanfaatkan menjadi lebih berguna. Jika dilihat, presentase bagian daging nya termasuk rendah yaitu hanya $20-35 \%$, sedangkan kulit 60\%-75\%, dan biji 5\%-15\% belum termasuk secara maksimal (Djaeni dan

Kulit durian memiliki nilai arus (Amphere) dan tegangan (Volt) yang cukup besar jika kita ukur menggunakan multimeter, sehingga kulit durian layak menjadi bagian penting dalam pembuatan bio-baterai ini. Selain itu kulit durian juga memiliki $\mathrm{pH}$ asam yang cukup tinggi sehingga dapat menyalakan sebuah lampu LED. Penelitian ini mencakup pengukuran nilai arus dan tegangan, juga tingkat keasaman dari bahan penelitian utama ini yaitu kulit durian.

Bio-Baterai adalah penyimpanan perangkat energi yang didukung oleh senyawa organik, biasanya menjadi glukosa, seperti glukosa dalam
Prasetyaningrum, 2010). Hasil penelitian Hatta (2007) menunjukan bahwa kulit durian mengandung unsur selulosa yang tinggi (50$60 \%$ ) dan kandungan lignin (5\%) serta kandungan pati yang lemah (5\%) sehingga dapat di olah menjadi sumber energi listrik alternatif terbarukan yang berupa bio-baterai.

darah manusia. Ketika enzim dalam tubuh kita memecah glukosa, beberapa elektron dan proton dilepaskan. Oleh karena itu, dengan menggunakan enzim untuk memecah glukosa, bio-baterai langsung menerima energi dari glukosa. Baterai ini kemudian menyimpan energi ini untuk digunakan nanti.

Saat ini energi terbarukan semakin digalakan, sebagai upaya mencari energi-energi alternatif lainnya. Berbagai aturan telah dibuat pemerintah agar dapat mengembangkan manajemen pengelolaan energi terbarukan di tanah air demi kesejahteraan masyarakat yang

Computer Science | Industrial Engineering | Mechanic Engineering | Civil Engineering 
berkesinambungan serta berdaulat dalam energi. Maka, pemerintah membentuk dewan energi nasional yang tugas pokok dan fungsinya merancang Kebijakan Energi Nasional (KEN).

Demi melaksanakan cita-cita tersebut, pemerintah membuat aturan khusus mengenai kebijakan energi nasional (KEN) yang tertuang melalui peraturan pemerintah (PP) Nomor 79 Tahun 2014, dimana peraturan tersebut merupakan panduan operasional bagi tata kelola kebijakan energi hingga 2050.

Lebih lanjut, sumber energi terbarukan juga dapat dihasilkan dari sumber daya energi yang dikelola dengan baik, antara lain panas bumi, angin, bioenergi, sinar matahari, aliran dan terjunan air, serta gerakan dan perbedaan suhu lapisan laut dengan tujuan terjaminnya ketersediaan energi.

\section{Pengertian Elektrokimia}

Menurut Dr. Fitria Rahwati (2013) elektrokimia merupakan suatu cabang ilmu kimia yang membahas konversi antara perubahan kimiawi dengan energi listrik. Elektrokimia sendiri dari waktu ke waktu telah mengalami perubahan tema pembahasan. Pada abad ke-16 sampai 17 elektrokimia lebih membahas prinsip-prinsip kimia yang berhubungan dengan sifat kemagnetan. Pembahasan kemudian beralih pada teori-teori tentang konduksivitas, muatan listrik serta metoda matematika yang digunakan untuk menjelaskan fenomena-fenomena tersebut. Saat ini, elektrokimia merupakan cabang ilmu kimia yang membahas tentang reaksi-reaksi kimia yang terjadi pada antarmuka elektroda dan elektrolit, dimana pada proses tersebut terjadi proses transfer elektron antara material elektroda dengan spesies-spesies dalam material elektrolit. Selanjutnya elektrokimia telah menjadi bidang riset tersendiri yang meliputi riset tentang baterai dan sel bahan bakar (fuell sell), riset tentang pencegahan korosi material serta riset-riset tersendiri tentang pengembangan metode permurnian logam dari hasil tambang melalui proses elektrolisis maupun elektroforesis.

\section{Dasar-dasar elektrokimia}

Menurut Riyanto (2013) elektrokimia merupakan bagian dari ilmu kimia yang mempelajari hubungan antara reaksi kimia dengan arus listrik. Elektrokimia dapat diaplikasikan dalam berbagai keperluan manusia, seperti keperluan sehari-hari dalam skala rumah tangga dan industri-industri besar seperti industri yang memproduksi bahan-bahan kimia organik maupun anorganik, farmasi, polimer, otomotiv, perhiasan, pertambangan, pengolahan limbah dan bidang analisis. Penggunaan elektrokimia diantaranya adalah :

.A. Sel gavani yaitu sel yang didasarkan pada reaksi kimia yang dapat menghasilkan arus listrik, seperti baterai, aki dan bahan bakar (fuell cell).

.B. Sel elektrolisis, yaitu sel yang didasarkan pada reaksi kimia yang memerlukan arus listrik. Contoh penggunaan sel elektrolisis yaitu :

1. Elektrodeposisi adalah pengendapan logam dipermukaan elektroda. Teknik ini digunakan untuk pembuatan bahan nanoteknologi, electroplating, pencegah korosi, perhiasan dan assesoris mobil.

2. Elektroanalisis adalah aplikasi pelektrolisis untuk analisis, seperti: polalografi, voltmetri, potensiometri, linier sweep voltmetri $(L S V)$, cyclic voltmetri $(C V)$, differential pulse voltmetri (DNPV), square wape voltmetri $(S W V)$, anodic stripping voltmetri (ASV), cathodic stripping voltmetri (CSV) dan voltametri strippng adsortif (AdSV).

3. Elektrosintetis adalah sintetis senyawa organik dan anorganik dengan cara elektrolisis. Teknik ini dapat mengatasi beberapa kelemahan sintetis dengan cara biasa. Beberapa senyawa organik dapat disintetis dengan cara elektrosintetis antara lain asam asetat, adiponitril, tetra alkil plumbun dan tetrafluoro-p-xlen, sedangkan sintetis senyawa anorganik antara lain $\mathrm{Ti}$, AI, Na, $\mathrm{MnO}_{2}, \mathrm{CI}_{2}$.

4. Elektrodegradasi adalah penguraian limbah organik dan anorganik. Penguraian limbah dengan teknik ini lebih efisien dan hemat energi. Hasil akhir dari penguraian limbah organik adalah air dan gas $\mathrm{CO}_{2}$, sedangkan limbah anorganik seperti logam-logam akan terendapkan di katoda. Logam yang sudah terendapkan di katoda, dapat dipisahkan dengan melarutkan logam tersebut dalam asam kuat, kemudian dipisahkan menjadi logam murni melalui pengendapan.

\section{METODE PENELITIAN}

Metode penelitian adalah suatu atau cara mencari, memperoleh, mengumpulkan, atau mencatat data, baik berupa data primer maupun 
sekunder yang digunakan untuk keperluan menyusun suatu karya ilmiah dan kemudian menganalisis faktor-faktor yang berhubungan dengan pokok-pokok permasalahan sehingga akan terdapat suatu kebenaran data-data yang akan diperoleh. Metode yang digunakan pada penelitian ini adalah metode kuantitatif. Penelitian kuantitatif adalah suatu proses menemukan pengetahuan yang menggunakan data berupa angka sebagai alat menemukan keterangan mengenai apa yang ingin kita ketahui.

\subsection{Tahapan Penelitian}

Penelitian ini terddiri atas dua tahapan yaitu tahap persiapan dan tahap pelaksanaan :

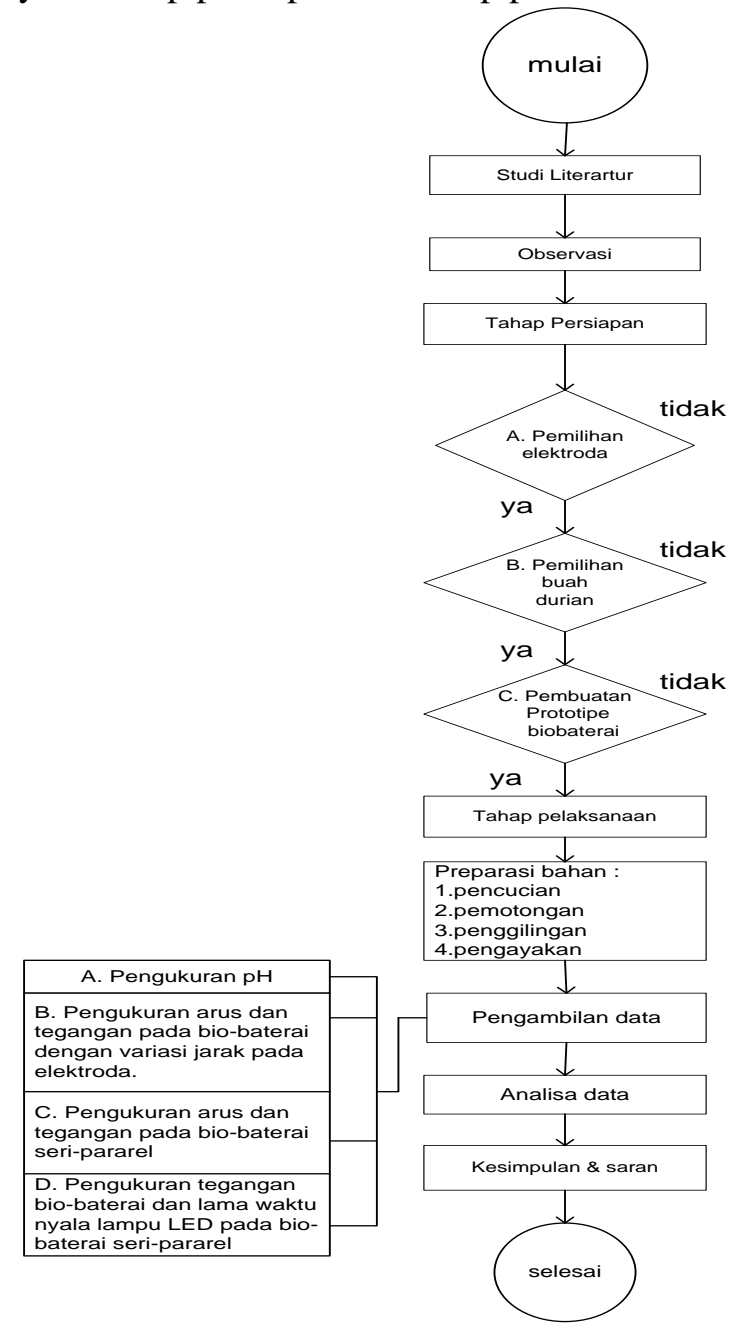

Gambar 1. Kerangka Penelitian

\section{HASIL DAN PEMBAHASAN}

Penelitian " Pengolahan Limbah Kulit Durian Menjadi Bio-Baterai Sebagai Energi Alternatif " ini mencakup pengaruh jarak antar elektroda terhadap nilai arus dan tegangan yang dihasilkan pada bio-baterai, nilai kuat arus dan tegangan pada bio-baterai seri-pararel dengan berbagai nilai hambatan, lama penyalaan LED yang dihasilkan oleh berbagai bio-baterai limbah kulit durian, serta hubungan nilai $\mathrm{pH}$ terhadap nilai tegangan. Berikut ini merupakan hasil pengukuran dari bio-baterai.

Preparasi sampel meliputi pencucian, pemotongan, dan penggilingan hingga kulit durian hancur dan menjadi lembut. Kulit durian yang digunakan sebagai sampel sebanyak 6 buah durian dari berbagai jenis.

Wadah prototype untuk limbah kulit durian menggunakan bahan plastik dari turperware berbentuk kotak, pada bagian penutup wadah diberi lubang masing-masing 6 lubang dengan jarak masing-masing $1 \mathrm{~cm} /$ lubang guna untuk memasangkan anoda (+), dan katoda (-). Berikut contoh gambar untuk prototype baterai.
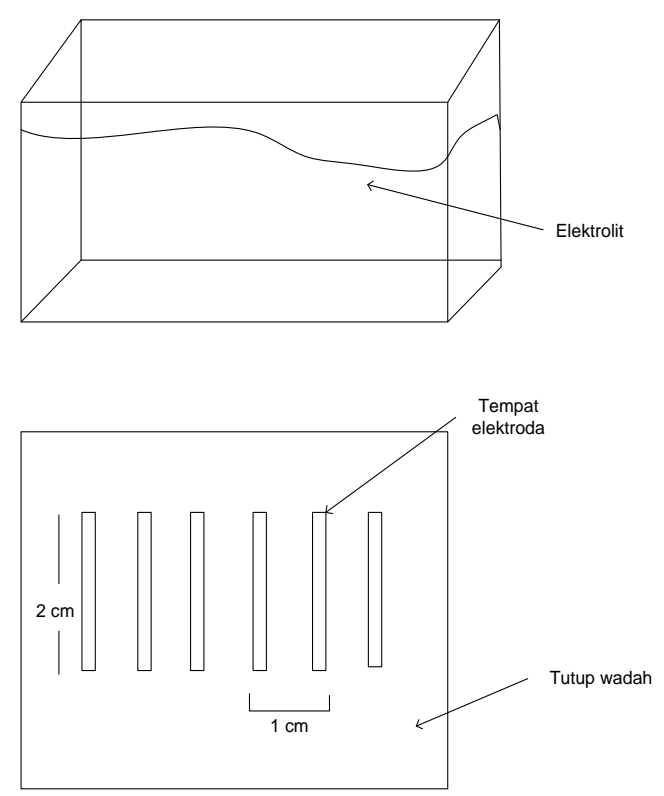

\section{Gambar 2. Wadah prototype Baterai}

Hasil pengukuran arus dan tegangan dengan empat kali pengulangan untuk bio-baterai limbah kulit durian ditampilkan pada tabel di lampiran. Pada tabel-tabel tersebut dapat dilihat nilai arus, tegangan, standar deviasi dan standar error dengan beberapa nilai resistor dan jarak antar elektroda oleh masing-masing wadah (prototype) bio-baterai limbah kulit durian.

Hasil pengukuran arus dan tegangan biobaterai dengan variasi jarak elektroda pada biobaterai tunggal limbah kulit durian disajikan pada grafik dibawah. Grafik hubungan kuat arus dan hambatan dengan berbagai jarak antar elektroda pada limbah kulit durian ditunjukan pada gambar 
4.9. terlihat pada grafik bahwa nilai kuat arus terbesar dimiliki oleh bio-bateri dengan jarak antar elektroda terdekat $(1 \mathrm{~cm})$ dengan hambatan $100 \Omega$ nilai kuat arus $1,00 \mathrm{~mA}$, semakin besar nilai hambatan yang diberikan maka semakin kecil kuat arus yang dihasilkan.

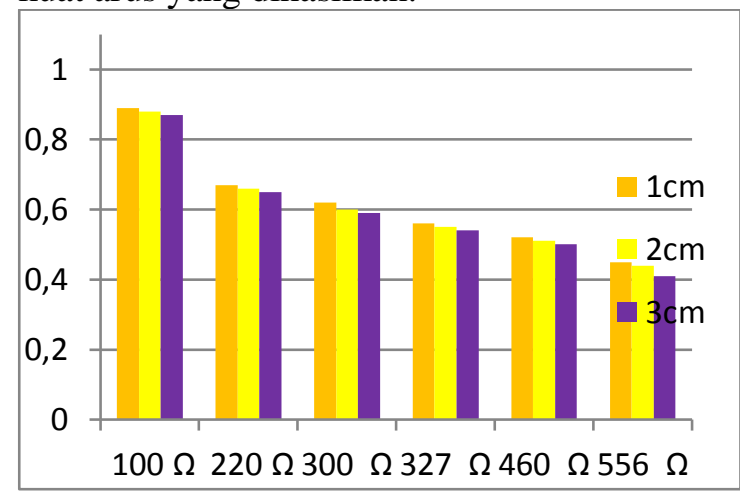

Gambar 3. Grafik hubungan kuat arus dan hambatan dengan berbagai jarak atar elektroda pada prototype 1 bio-baterai tunggal limbah kulit durian

Tabel 1. Nilai arus prototype 1

\begin{tabular}{|c|c|c|c|}
\hline hambatan & jarak 1cm & $\begin{array}{c}\text { jarak } \\
2 \mathrm{~cm}\end{array}$ & $\begin{array}{c}\text { jarak } \\
3 \mathrm{~cm}\end{array}$ \\
\hline 100 & 0,89 & 0,88 & 0,85 \\
\hline 220 & 0,67 & 0,66 & 0,65 \\
\hline 300 & 0,62 & 0,60 & 0,59 \\
\hline 327 & 0,56 & 0,55 & 0,54 \\
\hline 460 & 0,52 & 0,51 & 0,50 \\
\hline 556 & 0,45 & 0,44 & 0,41 \\
\hline
\end{tabular}

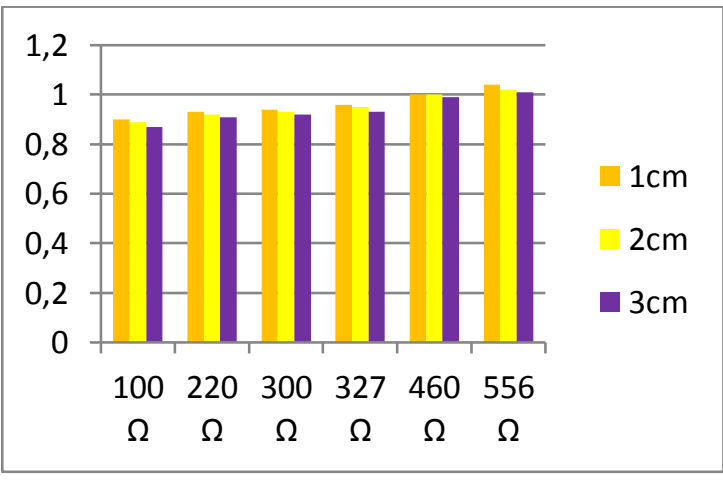

Gambar 4. Grafik hubungan tegangan dan hambatan dengan berbagai jarak antar elektroda pada prototype 1 bio-baterai tunggal limbah kulit durian

Tabel 2. nilai Tegangan prototype 1

\begin{tabular}{|l|c|c|c|}
\hline Hambatan & Jarak 1cm & $\begin{array}{c}\text { Jarak } \\
2 \mathrm{~cm}\end{array}$ & $\begin{array}{c}\text { Jarak } \\
3 \mathrm{~cm}\end{array}$ \\
\hline 100 & 0,90 & 0,89 & 0,87 \\
\hline 220 & 0,93 & 0,92 & 0,91 \\
\hline 300 & 0,94 & 0,93 & 0,92 \\
\hline
\end{tabular}

\begin{tabular}{|l|l|l|c|}
\hline 327 & 0,96 & 0,95 & 0,93 \\
\hline 460 & 1,00 & 1,00 & 0,99 \\
\hline 556 & 1,04 & 1,02 & 1,00 \\
\hline
\end{tabular}

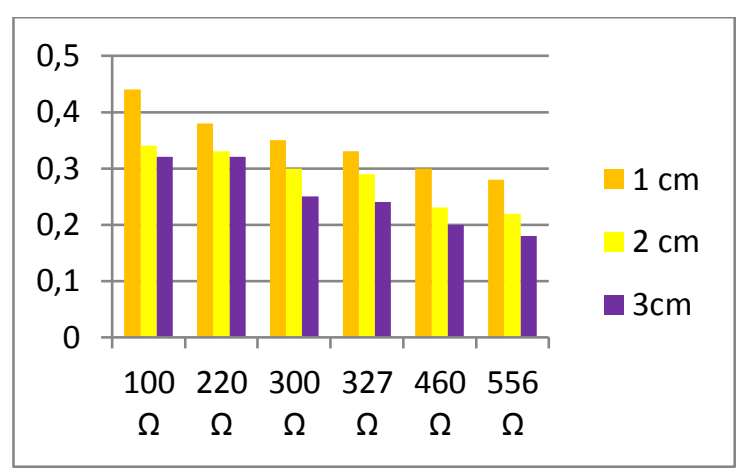

Gambar 5. Grafik hubungan kuat arus dan hambatan dengan berbagai jarak antar elektroda pada prototype 2 bio-baterai tunggal limbah kulit durian

Tabel 3. Nilai Kuat Arus prototype 2

\begin{tabular}{|c|c|c|c|}
\hline Hambatan & $\begin{array}{c}\text { Jarak } \\
1 \mathrm{~cm}\end{array}$ & $\begin{array}{c}\text { Jarak } \\
2 \mathrm{~cm}\end{array}$ & $\begin{array}{c}\text { Jarak } \\
3 \mathrm{~cm}\end{array}$ \\
\hline 100 & 0,44 & 0,34 & 0,32 \\
\hline 220 & 0,37 & 0,33 & 0,32 \\
\hline 300 & 0,35 & 0,30 & 0,25 \\
\hline 327 & 0,33 & 0,29 & 0,24 \\
\hline 460 & 0,30 & 0,27 & 0,20 \\
\hline 556 & 0,28 & 0,22 & 0,18 \\
\hline
\end{tabular}

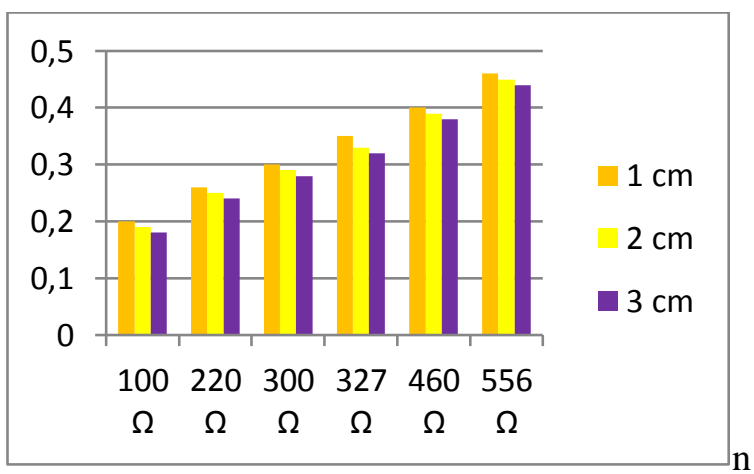

Gambar 6. Grafik hubungan teganga dan hambatan dengan berbagai jarak antar elektroda pada prototype 2 bio-baterai tunggal limbah kulit durian

Tabel 4 Nilai Tegangan Prototipe 2

\begin{tabular}{|c|c|c|c|}
\hline hambatan & $\begin{array}{c}\text { jarak } \\
1 \mathrm{~cm}\end{array}$ & $\begin{array}{c}\text { jarak } \\
2 \mathrm{~cm}\end{array}$ & $\begin{array}{c}\text { jarak } \\
3 \mathrm{~cm}\end{array}$ \\
\hline 100 & 0,20 & 0,19 & 0,18 \\
\hline 220 & 0,26 & 0,25 & 0,24 \\
\hline 300 & 0,30 & 0,29 & 0,28 \\
\hline 327 & 0,35 & 0,33 & 0,32 \\
\hline 460 & 0,40 & 0,39 & 0,38 \\
\hline
\end{tabular}




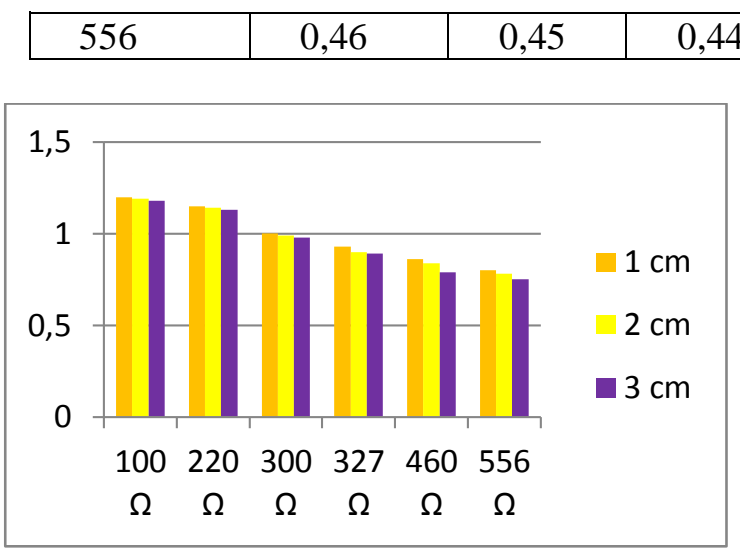

Gambar 7. Grafik hubungan kuat arus dan hambatan dengan berbagai jarak antar elektroda pada prototype 3 bio-baterai tunggal limbah kulit durian

Tabel 5 Nilai Kuat Arus Prototipe 3

\begin{tabular}{|c|c|c|c|}
\hline hambatan & jarak $1 \mathrm{~cm}$ & $\begin{array}{c}\text { jarak } \\
2 \mathrm{~cm}\end{array}$ & $\begin{array}{c}\text { jarak } \\
3 \mathrm{~cm}\end{array}$ \\
\hline 100 & 1,20 & 1,19 & 1,18 \\
\hline 220 & 1,15 & 1,14 & 1,13 \\
\hline 300 & 1,00 & 0,99 & 0,98 \\
\hline 327 & 0,93 & 0,90 & 0,89 \\
\hline 460 & 0,86 & 0,84 & 0,79 \\
\hline 556 & 0,80 & 0,78 & 0,75 \\
\hline
\end{tabular}

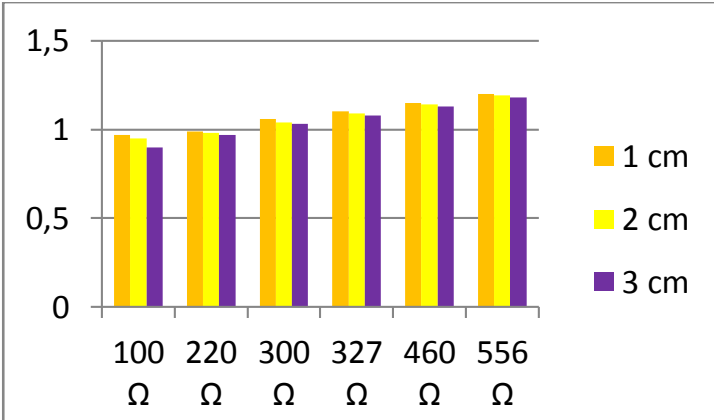

Gambar 8 Grafik hubungan tegangan dan hambatan dengan berbagai jarak antar elektroda pada prototype 3 bio-baterai tunggal limbah kulit durian

Tabel 6 Nilai Tegangan Prototipe 3

\begin{tabular}{|c|c|c|c|}
\hline hambatan & jarak $1 \mathrm{~cm}$ & jarak $2 \mathrm{~cm}$ & jarak $3 \mathrm{~cm}$ \\
\hline 100 & 0,97 & 0,95 & 0,90 \\
\hline 220 & 0,99 & 0,98 & 0,97 \\
\hline 300 & 1,06 & 1,04 & 1,03 \\
\hline 327 & 1,10 & 1,09 & 1,08 \\
\hline 460 & 1,15 & 1,14 & 1,13 \\
\hline 556 & 1,20 & 1,19 & 1,18 \\
\hline
\end{tabular}

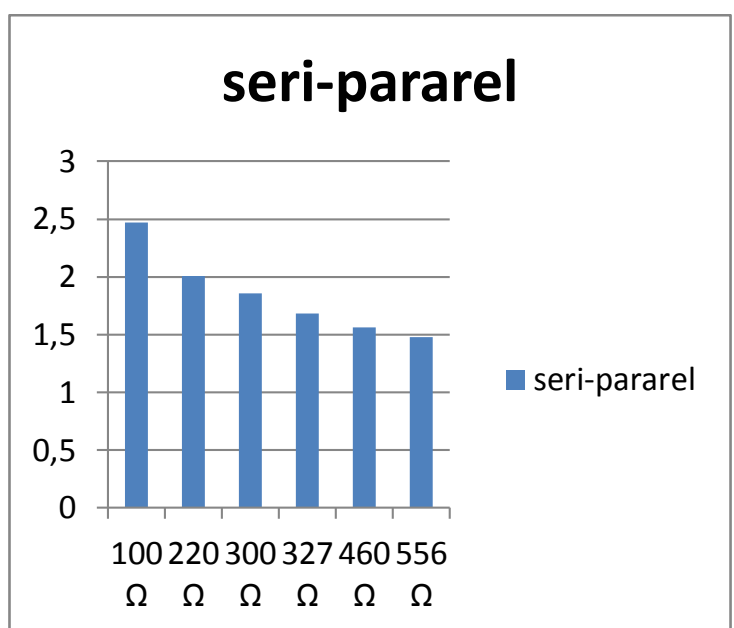

Gambar 9 grafik hubungan kuat arus dan hambatan limbah kulit durian seri-pararel biobaterai limbah kulit durian.

\begin{tabular}{|c|c|}
\hline hambatan & seri-pararel \\
\hline 100 & 2,47 \\
\hline 220 & 2,01 \\
\hline 300 & 1,86 \\
\hline 327 & 1,68 \\
\hline 460 & 1,56 \\
\hline 556 & 1,48 \\
\hline
\end{tabular}

\section{seri-pararel}

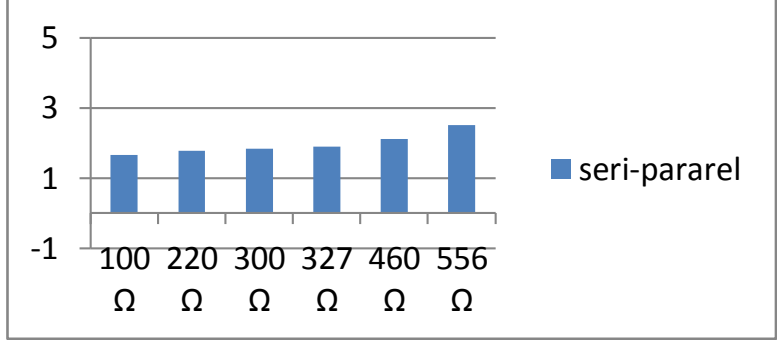

Gambar 10 grafik hubungan tegangan dan hambatan limbah kulit durian seri- pararel biobaterai limbah kulit durian.

\section{Uji Hipotesis Statistik}

Uji hipotesis menggunakan uji regresi linier sederhana untuk mengetahui mean atau nilai ratarata, dan standar deviasi atau simpangan baku. Kuat Arus

\section{Descriptive Statistics}

\begin{tabular}{|l|r|r|r|}
\hline & N & Mean & $\begin{array}{c}\text { Std. } \\
\text { Deviation }\end{array}$ \\
\hline Prototipe 1 & 6 & 1,8550 &, 46064 \\
Valid N & 6 & & \\
(listwise) & & & \\
\hline
\end{tabular}


Descriptive Statistics

\begin{tabular}{|c|c|c|c|}
\hline & $\mathrm{N}$ & Mean & $\begin{array}{c}\text { Std. } \\
\text { Deviation }\end{array}$ \\
\hline $\begin{array}{l}\text { Prototipe } \\
2 \\
\text { Valid N } \\
\text { (listwise) }\end{array}$ & 6 & 1,0350 &, 17050 \\
\hline
\end{tabular}

Descriptive Statistics

\begin{tabular}{|l|r|r|r|}
\hline & N & Mean & $\begin{array}{c}\text { Std. } \\
\text { Deviation }\end{array}$ \\
\hline Prototipe 3 & 6 & 2,9700 &, 47699 \\
Valid N \\
(listwise)
\end{tabular}

Berdasarkan output nilai kuat arus diatas $\mathrm{N}$ atau banyaknya data hambatan adalah 6 dari data valid 6 dari berbagai prototipe. Sedangkan pada prototype 1 mean atau nilai rata-rata nya 1,8550 $\mathrm{mA}$, standar deviasi atau simpangan baku yaitu $46064 \mathrm{~mA}$. Pada prototype 2 mean atau nilai ratarata nya $1,0350, \mathrm{~mA}$ standar deviasi atau simpangan baku yaitu ,17050mA. Pada prototype 3 mean atau nilai rata-rata nya $2,9700, \mathrm{~mA}$ standar deviasi atau simpangan baku yaitu ,47699mA.

Tegangan

Descriptive Statistics

\begin{tabular}{|l|r|r|r|}
\hline & N & Mean & $\begin{array}{c}\text { Std. } \\
\text { Deviation }\end{array}$ \\
\hline Prototipe 1 & 6 & 2,8850 &, 15228 \\
Valid N \\
(listwise)
\end{tabular}

Descriptive Statistics

\begin{tabular}{|l|r|r|r|}
\hline & N & Mean & $\begin{array}{c}\text { Std. } \\
\text { Deviation }\end{array}$ \\
\hline Prototipe 2 & 6 &, 9767 &, 27075 \\
Valid N & 6 & & \\
(listwise) & & & \\
\hline
\end{tabular}

Descriptive Statistics

\begin{tabular}{|l|r|r|r|}
\hline & N & Mean & $\begin{array}{c}\text { Std. } \\
\text { Deviation }\end{array}$ \\
\hline Prototipe 3 & 6 & 3,235 &, 26928 \\
$\begin{array}{l}\text { Valid N } \\
\text { (listwise) }\end{array}$ & 6 & 0 & \\
\hline
\end{tabular}

Berdasarkan output nilai tegangan diatas $\mathrm{N}$ atau banyaknya data hambatan adalah 6 dari data valid 6 dari berbagai prototipe. Sedangkan pada prototype 1 mean atau nilai rata-rata nya 2,8850 volt standar deviasi atau simpangan baku yaitu ,15228 volt. Pada prototype 2 mean atau nilai rata-rata nya ,9767,volt standar deviasi atau simpangan baku yaitu ,27075 volt. Pada prototype 3 mean atau nilai rata-rata nya 3,2350 volt, standar deviasi atau simpangan baku yaitu ,26928volt.

\section{KESIMPULAN}

Dilihat pada hasil dan analisis dan pengujian yang telah dilakukan secara keseluruhan pada pengolahan limbah kulit durian, maka penulis dapat menyimpulkan :

1. Pengolahan kulit durian menjadi bio-baterai meliputi pencucian agar kotoran yang menempel pada kulit durian hilang, kemudian sampel di potong menjadi bagianbagian kecil agar dapat di giling dengan merata. Dibutuhkan 6 buah durian untuk ke 9 wadah prototipe.

2. Hasil pengukuran arus dan tegangan biobaterai dengan variasi jarak dapat disimpulkan bahwa prototype 3 memiliki arus dan tegangan terbesar dengan nilai hambatan $100 \Omega-556 \Omega$ adalah sebesar $(1,20$ $0,80) \mathrm{mA}$, sedangkan nilai tegangan nya adalah $(0,97-1,20)$ volt untuk jarak elektroda $1 \mathrm{~cm}$ (jarak optimal).

3. Nilai kuat arus dan tegangan pada susunan seri-pararel akan bertambah 3 kali lipat dibanding bio-baterai tunggal dengan masing-masing nilai hambatan $100 \Omega-556 \Omega$ adalah 2,47-1,48 mA, sedangkan tegangan nya adalah 1,65-2,50 volt.

4. Hubungan $\mathrm{pH}$ dengan tegangan bio-baterai limbah kulit durian lebih ke tingkat keasaman suatu sampel, dimana semakin tinggi asam suatu sampel maka daya dan tegangan listrik akan semakin baik. Pada prototype 3 memiliki tingkat keasaman yang tinggi dengan nilai $\mathrm{pH}$ 2,5 dan tegangan yang dihasilkan 1,20 volt.

\section{REFERENSI}

Dr.Fitria Rahmawati. 2013, Elektrokimia Transformasi Energi Kimia-Listrik, Erlangga: Yogyakarta.

Riyanto. 2013, Elektrokimia dan Aplikasinya, Erlangga: Yogyakarta.

Aisiyah, N. 2013, Efek Variasi Bahan Elektroda Serta Variasi Jarak Antar Elektroda Terhadap Kelistrikan Yang Dihasilkan Oleh Limbah Buah Jeruk, Skripsi. Program Studi 
Fisika, Universitas Jember, Jember.

Hana Kholida. 2015, Pengaruh Kuat Arus Listrik Dengan Keasaman Buah Jeruk, Seminar Nasional Fisika dan Pendidikan Fisika, Surakarta.

Suci, Asmarani. 2017, Analisis Jeruk Dan Kulit Jeruk Sebagai Larutan Elektrolit, Skripsi.

Program Studi Fisika, Universitas Lampung, Lampung.

Devi Yulianti. 2016, Analisis Kelistrikan Sel Volta Memanfaatkan Logam Bekas, Skripsi, Program Studi Fisika, Universitas Lampung, Lampung.

Gita Anggaretno, dkk. 2012, Analisa Pengaruh Jenis Elektroda terhadap Laju Korosi pada Pengelasan Pipa API 5L Grade X65dengan Media Korosi FeCl3. Skripsi. Program Studi Teknik Kelautan Institut Teknologi Sepuluh November (ITS), Surabaya.

EndangWidjajanti. 2005, Sel-sel Elektrolisis Dalam Pengembangan Elektrokimia, Skripsi.

Program Studi Fisika Universitas Negri Malang, Malang.

Khairiah Rita. 2017, Analisis Kelistrikan Pasta Elektrolit Limbah Kulit Durian, Seminar Nasional Pendidikan, Serang.

Bernardinus T, dkk. 2008, Sukses Bertanam Durian, Agromedia: Jakarta.

Wira Dian Jauharah. 2013, Analisis Kelistrikan Yang Dihasilkan Limbah Buah Dan Sayuran Sebagai Energi Alternatif Bio-Baterai, Skripsi. Program Studi Fisika Universitas Jember, Jember.

Didik Hariyanto. 2009, Penentuan Nilai Resistor Menggunakan Seleksi Warna Model HIS Pada Citra 2D, https://researchgate.net/publication/28645356 3, diakses tanggal: 25 Mei 2018.

Pernantin Tarigan. 2012, Dasar Teknik Digital, Graha Ilmu: Yogyakarta.

Aditya Satriady. 2016, Pengaruh Luas Elektroda Terhadap Karakteristik Baterai LiFePO , Skripsi. Program Studi Fisika, Universitas Padjadjaran, Sumedang. 